\title{
Phenomenal intentionality past and present: introductory
}

\author{
Uriah Kriegel
}

Published online: 25 April 2013

(C) Springer Science+Business Media Dordrecht 2013

Keywords Phenomenal intentionality Intentional state $\cdot$ Philosophy of mind

A growing amount of research on intentionality within Anglo-American philosophy of mind has been focusing on the notion of phenomenal intentionality. How to characterize phenomenal intentionality is not a straightforward matter, but one relatively neutral option is in terms of counterfactual dependence: an intentional state has phenomenal intentionality just in case if it were not phenomenal it would not be intentional. ${ }^{1}$ Research focusing on phenomenal intentionality has tended to be guided by two insights. The first is that phenomenal intentionality is distinctive: it has certain special features lacking in other kinds of intentionality. The second is that phenomenal intentionality is basic: it enjoys some sort of priority, whether metaphysical or epistemological, over other kinds of intentionality. Commitment to these two claims has been the mark of an emerging research program for understanding intentionality. ${ }^{2}$ Different treatments of intentionality within the research program differ in terms of how acutely distinctive and how importantly basic they take phenomenal intentionality to be.

There is a limit case of this genre of theory that treats phenomenal intentionality as the only kind of intentionality. ${ }^{3}$ Galen Strawson sometimes seems committed to this particularly strong position (Strawson 2008). It is very plausible, however, that this position was commonplace among philosophers of mind in the so-called Brentano School. Certainly it is plausibly attributed to Brentano (1874), who did not use the

\footnotetext{
${ }^{1}$ I discuss this and other construals of "phenomenal intentionality" in Kriegel (2011), Ch.1.

${ }^{2}$ For some key texts in this burgeoning research program, see Loar (1987, 2003), McGinn (1988), Searle (1990, 1992), Strawson (1994, 2008), Horst (1996), Siewert (1998), Horgan and Tienson (2002), Kriegel (2003, 2011), Georgalis (2006), and Bourget (2010). I attempt to summarize the main strands in the research program in Kriegel forthcoming.

${ }^{3}$ If so, phenomenal intentionality's distinctiveness is acute as can be and its basicness important as can be. Hence "limit case"!
} 
term "phenomenal" in the same sense but did hold that all intentionality was conscious. Moreover, since, for Brentano, intentionality is the mark of the mental, and all mentality is conscious, he is also committed to the aforementioned counterfactual: a mental state could not be intentional if it were not conscious. Thus Brentano can be seen as an early proponent of (1) the existence of phenomenal intentionality and (2) the nonexistence of nonphenomenal intentionality.

From Brentano, the focus on conscious or phenomenal intentionality has propagated to Carl Stumpf's Berlin School, Anton Marty's Prague School, Alexius Meinong's Graz School, Kasimir Twardowski's Lvov School, and Husserlian Phenomenology. This special issue is dedicated to work on intentionality within this tradition, with the hope that contemporary work on phenomenal intentionality could learn something from these early contributions. In this introductory, I present some of the historical and intellectual context and place the papers making up this issue in that context.

It is well known that Brentano took intentionality to be the mark of the mental, where this means that intentionality co-extends with mentality (1874 II Ch.1). It is less well known that Brentano also took the mental and the conscious to co-extend (1874 II Ch.2). It follows that intentionality and consciousness co-extend as well. Moreover, Brentano's notion of consciousness appears to be the phenomenal notion, at least if the term "phenomenal" is construed as referring to the phenomenon that presents a special challenge to a physicalist worldview. ${ }^{4}$ Thus it appears that, for Brentano, a state is intentional iff it is phenomenal. It is not textually obvious whether this is supposed to have counterfactual depth, such that if a given intentional state were not phenomenal, it would not be intentional either. But arguably, there is no reason to suspect Brentano would deny this. If so, it is plausible to attribute the following thesis to Brentano: every intentional state is phenomenal-intentional. In other words, phenomenal intentionality is the only intentionality. ${ }^{5}$

The Brentanian notion of intentionality was brought into analytic Anglo-American philosophy by Chisholm (1957). ${ }^{6}$ Nonetheless, the phenomenal characterization of intentionality in Brentano was lost in much subsequent work on intentionality in the Anglo sphere. To that extent, the recent revival of interest in phenomenal intentionality among analytic philosophers could enjoy further inspiration by a reconsideration of central work on intentionality within the Brentano School. This special issue attempts to make a focused contribution to this reconsideration, with articles on the notion of intentionality in six prominent philosophers in the Brentanian tradition: Brentano,

\footnotetext{
${ }^{4}$ This understanding of the function of "phenomenal" is present in Block (1995, p. 382) and Kriegel (2009, Ch.1). Brentano himself was a dualist (1874 Bk I Ch3) and so was committed to the challenge in question being a successful one.

${ }^{5}$ The co-extension of mentality, intentionality, and consciousness guarantees not only that all intentional states are conscious, but also that all mental states are consciously intentional, including nonperceptual, purely intellectual states, such as thoughts, judgments, suppositions, etc. These would be forms of what Anglo-American philosophers call "cognitive phenomenology."

${ }^{6}$ Chisholm was so impressed by Brentano as a philosopher that he translated a number of his works into English.
} 
Twardowski, Husserl, Sartre, Gurwitsch, and Ricœur. The remainder of this introductory provides an initial introduction to these figures and the articles dedicated to them here.

The intellectual family tree of the Brentano School is impressively elaborate (see the "Schema" after this article). Franz Clemens Brentano (1838-1917) received his doctorate from Tübingen in 1862 and was ordained as a catholic priest 2 years later. According to Brentano, every conscious experience exhibits two kinds of intentionality: a primary intentionality directed at the outside world, and a secondary intentionality directed at itself. Thus, an auditory experience of trumpets, Brentano tells us, is primarily directed at the trumpet sounds and secondarily directed at itself, the experience of hearing those sounds (1874 Bk II Ch.3). Accordingly, we have included here two papers on Brentano's account of intentionality. Arnaud Dewalque's "Brentano and the Parts of the Mental" is devoted to primary intentionality while Mark Textor's "Brentano on the Dual Relation of the Mental" is focused on secondary intentionality.

Dewalque argues that Brentano's mereology (developed most fully in his Descriptive Psychology) provides us with tools for analyzing the relationship between the phenomenal and the intentional aspects of phenomenal intentionality. Above, I characterized phenomenal intentionality in terms of the counterfactual dependence of the intentional on the phenomenal. But there are two common views on what underlies this counterfactual dependence: on an asymmetric view, the intentional is grounded in the phenomenal, which is thus metaphysically prior to it; on a symmetric view, the intentional and the phenomenal are strictly identical, so neither is metaphysically more fundamental. After pointing out the difficulties that attend both views, Dewalque proposes a Brentanian alternative according to which the phenomenal and the intentional are "distinctional parts" of a single phenomenon. Brentano distinguishes two kinds of parthood: based on separability and based on distinguishability. The material particles composing a molecule are separable from each other, in that each can exist without the other, and so are different separable parts of the molecule. The left half and right half of a single particle are not separable, in that they cannot exist without the other, but they are still distinguishable from each other; they are thus distinctional parts. Similarly, argues Dewalque, phenomenology and intentionality are distinctional parts of a single mental phenomenon: neither can exist without the other, but they can still be distinguished from each other.

As mentioned, Textor's paper is dedicated to this secondary intentionality. In particular, Textor reconstructs and firms up Brentano's case for the thesis that every mental state constitutes an awareness of itself. As Textor sees it, for Brentano, the claim is self-evident and requires only a negative defense: the fending off of temptations to doubt it that are grounded in various philosophical misconceptions. In the process of neutralizing these misconceptions, however, a portrait of this secondary intentionality arises: to have inner awareness of one's mental state is to have a kind of immediately evident but nonattentive acknowledgement of the fusion of that state and the awareness.

Brentano spent the first 7 years of his academic career (1866-1873) in Würzburg. On 14 July 1866, Brentano met his first major student, Carl Stumpf (1848-1936), who proceeded to study with him for the following 4 years, before ultimately setting up the "Berlin School," wherefrom sprang leading Gestalt psychologists Max Wertheimer (1880-1943), Kurt Koffka (1886-1941), and Wolfgang Köhler (18871967). These in turn had a great influence on Aron Gurwitsch's (1901-1973) Gestalt- 
centered phenomenology, discussed below in Chudnoff's essay "Gurwitch's Phenomenal Holism." Phenomenal holism, for Chudnofff, is the thesis that every experience a person has at a given time metaphysically depends upon that subject's overall conscious experience ("total phenomenal state") at that time. The reason for this is that (1) part of the phenomenal character of an experience is a matter of its position on the spectrum from focal theme to peripheral margin in the subject's overall field of consciousness, but (2) this position depends on all the subject's other experiences at the same time.

Despite his influence through the Berlin School, the most important Thesis Stumpf directed is arguably Husserl's, which he directed in 1887, before arriving to Berlin in 1894. Stumpf's own contributions were in epistemology and ethics, where the notion of intentionality was used routinely but thematized rarely.

Two years after meeting Stumpf, Brentano met his other major student from Würzburg, Anton Marty (1847-1914). As a seminary student, Marty read Brentano's interpretive works on Aristotlian metaphysics and wrote a prize-winning essay discussing them in 1867. The next year he went to Würzburg for the express purpose of studying with Brentano (Stumpf and Marty became friends for life in that period). Marty's interests throughout his career were primarily ontological, but he is also known for his application of Brentano's descriptive psychology to language, producing a kind of "descriptive semantics." His career culminated in the rectorship of the University of Prague, where the "Prague School" produced some of the most Orthodox Brentanians, such as Oscar Kraus (1872-1942), Alfred Kastil (18741950), and Franziska Mayer-Hillebrand (1885-1977).

In 1874, Brentano took up a professorship in Vienna. It is here that he met his most important students. The first was Alexius Meinong (1853-1920), who studied with Brentano from 1875 to 1878 and taught in Graz from 1882 to the end of his life. Meinong's contributions to the study of intentionality, especially "The Theory of Objects" (Meinong 1904) are probably better known to the analytic philosopher than other contributions from the Brentano School, probably due to their engagement by Russell (1905). Less well known is Meinong's influence on a whole further generation of philosophers in his "Graz School," including Stephan Vitasek (1870-1915), Vittorio Benussi (1878-1927), and Ernst Mally (1879-1944).

In 1880, Brentano was forced to resign his chair at the University of Vienna and become a privatdozent, after losing his Austrian citizenship (as a result of marrying despite being an ordained priest). But his influence was only to increase thereafter. In the same year, Brentano met Christian von Ehrenfels (1859-1936), who studied with him until 1883 and spent most of his own career at the University of Prague. Ehrenfels' (1890) early work foreshadows Gestalt theory, and one of his own first students was the aforementioned Max Wertheimer from the Berlin School. However, Ehrenfels' (1897/8) most developed work was in ethics, which presents a systematic axiology based somewhat on Brentano's (1889) work on the origins of right and wrong.

Two years after Ehrenfels' graduation, in 1885, Brentano met one of his greatest students: Kasimierz Twardowski (1866-1938), who wrote his 1891 thesis, Idea and Perception: An Epistemological Study of Descartes, under the guidance of Brentano, though it was formally supervised by the then-influential Robert Zimmerman (since a privatdozent could not formally supervise a dissertation). Three years later, at the 
tender age of 28, Twardowski (1894) published his astonishing little book On the Content and Object of Presentations, effectively a comprehensive theory of the structure of intentionality. Although it immediately attracted great attention in Central European philosophy, prompting Husserl to publish a 50-page discussion (along with a shorter review) of Twardowski's 100-page treatise, it was staunchly disregarded in Anglo-American philosophy (it was first translated into English only in 1977). ${ }^{7}$ A year after the book's appearance, Twardowski was appointed professor at the University of Lvov, where he set up the "Lvov School" and taught some of the greatest Polish logicians of the twentieth century-Jan Lukasiewicz (1878-1956), Stanisław Leśniewski (1886-1939), and Alfred Tarski (1901-1983) — as well as the intriguing nominalist ontologist Tadeusz Kotarbiński (1886-1981).

Perhaps Twardowski's best-known contribution to the Brentanian tradition on intentionality is the distinction between intentional content and intentional object. The distinction is quite similar, and is motivated similarly, to Frege's (1892) distinction between sense and reference. John Tienson's "Kasimir Twardowski on the Content of Presentations" attempts to provide an account of this notion of intentional content. On Tienson's interpretation, intentional contents are intrinsic to mental acts and, unlike intentional objects, are not actually presented. Rather, the object is presented through them. The exact relation between content and object depends, says Tienson, on whether the presentation in question is simple or complex. A simple presentation is one that presents no mereological structure in the object. In such presentations, the relation the content bears to the object, in virtue of which the presentation bearing that content presents that object, is primitive and inexplicable - it is a sui generis relation. For complex presentations, however, the content-object relation can be accounted for in terms of (1) this sui generis relation implicated in simple presentations and (2) the mereological structure of the object (its different material and formal constituents in need of presenting).

Brentano's most famous philosophical student was doubtless Edmund Husserl (1859-1938). ${ }^{8}$ Husserl went to Vienna to study with Brentano from 1884 to 1886 , on the advice of his Leipzig mentor (and Brentano's ex student) Thomas Masaryk. Husserl spent the lion's share of his career in Göttingen, but spent a dozen years in Freiburg as well, before retiring in $1928 .{ }^{9}$ His phenomenology propagated through German academia with stunning speed, though interestingly, many of its most prominent followers - such as Alexander Pfänder (1870-1941), Max Scheler (1874-1919), and Martin Heidegger (1889-1976) — retained strong intellectual independence and were not personally very close to Husserl.

In "Husserl's Hyletic Data and Phenomenal Consciousness," Kenneth Williford offers an interpretation of Husserl's conception of intentionality as crucially invoking something like what Harman (1990) and Block (1996) refer to as "mental paint": intrinsic, nonrepresentational properties of intentional act that Husserl calls hyletic data.

\footnotetext{
7 The reason for this is unclear to me, but my sense is that if we treat Twardowski's account as targeting specifically phenomenal intentionality — which we must, since he recognized no other - the account would come across as much more compelling.

${ }^{8}$ Brentano's best-known student overall would have to be Freud. The exact relationship between the two is unclear, but in a 1932 letter to Theodore Gomperz, Freud asserts unequivocally that he was a student of Brentano's (see Merlan 1945).

${ }^{9}$ It is in Freiburg that Husserl met who was his assistant from 1919 to 1923.
} 
These hyletic data ground intentional directedness insofar as they are susceptible to being intentionally animated, that is, in some sense "interpreted" as directed at worldly objects and states of affairs. Williford defends the view as not only Husserlian but also plausible.

Husserl's infiltration of the French philosophical scene was much more circuitous. Although in 1929 Husserl delivered in Paris four lectures presenting a condensed, big-picture portrait of his transcendental phenomenology (later to be the basis for the Cartesian Meditations (Husserl 1931)), Jean-Paul Sartre (1905-1980) heard of Husserl only a couple of years later from his friend (and a giant of sociology and history in his own right) Raymond Aron, who had just returned from residence at the French Institute in Berlin. Upon hearing from Aron that someone in Germany found a way to make philosophy out of everyday life, Sartre spent the academic year 1933-4 at the French Institute as well, and in 1936 published the short but brilliant The Transcendence of the Ego (1936). Seven years later appeared his main phenomenological work, Being and Nothingness (Sartre 1943).

Mark Rowlards' "Sartre, Consciousness, and Intentionality" offers an account of Sartrean intentionality. The key thesis in Sartre's account, according to Rowlands, is that consciousness has no content. A conscious experience has an intentional object it is directed upon, and every such intentional object is external to consciousness - it is a mind-transcendent object. There is never any object of consciousness that is internal to consciousness or somehow part of consciousness. Moreover, the intentional relation between the experience and its object is never mediated by a third entity we might call "intentional content," as is often held following Twardowski. For Sartre, this starkly externalist conception of intentionality falls out of two relatively straightforward ideas. The first is that consciousness is possessed of original or underived intentionality. The second is that no objects of consciousness can be intentional in this original/underived way. This second idea is the more controversial, and accordingly, Rowlands spends the heart of his paper defending it.

It is sometimes thought that the realist and externalist twist Sartre's work gave to Husserlian phenomenology had a lasting effect on French phenomenology, including the work of Emmanuel Levinas (1906-1995), Maurice Merleau-Ponty (1908-1961), and Paul Ricœur (1913-2005). ${ }^{10}$ Of these, only Levinas actually studied with Husserl; his thesis on Husserl's notion of intuition (Levinas 1930), published when he was 24 , is a masterpiece of succinct and well-organized presentation of the main ideas of Husserl's phenomenology. ${ }^{11}$

In my own contribution to this issue, "Understanding Conative Phenomenology: Lessons from Ricœur," I examine Ricœur's central ideas on the intentionality characteristic of the conscious will. In the functionalist literature that has dominated the philosophy of mind of the last generation, the paradigmatic conative state is considered to be desire (with some of this literature also focusing on intention). According to Ricœur, however, from a first-person point of view, the (experientially) paradigmatic conative state is not desire, but a kind of episode of exercising the will

\footnotetext{
$\overline{10}$ There are of course exceptions to this rule, such as in the work of Jean-Toussaint Desanti (19142002)—see Desanti (1963).

${ }^{11}$ It is a legitimate question which work does the better job of giving a compact sense of the entire enterprise, Levinas' thesis or Husserl's Cartesian Meditations - whose first translation into French is actually by Levinas himself (together with Gabrielle Peiffer).
} 
characterized by three aspects: deciding, acting, and consenting. In my paper, I argue that Ricœur is right to focus on deciding rather than desiring, but that (1) the experience of trying is the better complement to deciding than the experience of acting, and (2) consenting is not plausibly a third and separate aspect of experience but more likely just a special kind of deciding. The upshot is that the phenomenologically paradigmatic act of the will is that of deciding and then trying.

The essays collected here do not, unfortunately, constitute a representative overview of phenomenological and proto-phenomenological work on intentionality. Much relevant work that could inform current research on phenomenal intentionality is not so much as mentioned below. Still, the hope is that this volume will inspire further research along the lines pursued in the essays below. For such research is sure to be mutually beneficial both to philosophers of mind interested in phenomenal intentionality and to historians of philosophy (especially early analytic philosophy and phenomenology) interested in new perspectives from which to investigate historical works. The hope is that the essays collected here make a preliminary case for the potential fruitfulness of such avenues of research.

\section{References}

Block, N. J. (1995). 'On a confusion about the function of consciousness.' Behavioral and Brain Sciences 18: 227-247. Reprinted in N. J. Block, O. Flanagan, and G. Guzeldere (eds.), The Nature of Consciousness. Cambridge: MIT Press.

Block, N. J. (1996). Mental paint and mental latex. Philosophical Issues, 7, 19-50.

Bourget, D. (2010). Consciousness is underived intentionality. Nô̂s, 44, 32-58.

Brentano, F. (1874). Psychology from empirical standpoint. Edited by O. Kraus. English edition: McAlister, L.L. (1973). (Translated by A. C. Rancurello, D. B. Terrell, and L. L. McAlister.). London: Routledge and Kegan Paul.

Brentano, F. (1889). The origin of our knowledge of right and wrong. In R. Chisholm \& E. H. Schneewind (Eds.), Trans. London: Routledge and Kegan Paul. 1969.

Chisholm, R. (1957). Perceiving: a philosophical study. Ithaca: Cornell UP.

Desanti, J.-T. (1963). Phénoménologie et praxis. Paris: Editions sociales.

Georgalis, N. (2006). The primacy of the subjective. Cambridge: MIT Press.

Harman, G. (1990). The intrinsic quality of experience. Philosophical Perspectives, 4, 31-52.

Horgan, T., \& Tienson, J. (2002). The intentionality of phenomenology and the phenomenology of intentionality. In D. J. Chalmers (Ed.), Philosophy of mind: classical and contemporary readings. Oxford UP: Oxford.

Horst, S. (1996). Symbols, computation and intentionality. Berkeley: University of California Press.

Husserl, E. (1931). Cartesian meditations. Trans. D. Cairns. Dordrecht: Kluwer.

Kriegel, U. (2003). Is intentionality dependent upon consciousness? Philosophical Studies, 116, 271-307. Kriegel, U. (2009). Subjective Consciousness: A Self-Representational Theory. Oxford: Oxford University Press. Kriegel, U. (2011). The sources of intentionality. Oxford: Oxford University Press.

Levinas, E. (1930). La théorie de l'intuition dans la phénoménologie de Husserl. Paris: Vrin.

Loar, B. (1987). Subjective intentionality. Philosophical Topics, 15, 89-124.

Loar, B. (2003). Phenomenal intentionality as the basis for mental content. In M. Hahn \& B. Ramberg (Eds.), Reflections and replies: essays on the philosophy of Tyler Burge. Cambridge: MIT Press.

McGinn, C. (1988). 'Consciousness and Content.' Proceedings of the British Academy 76: 219-239. Reprinted in N. J. Block, O. Flanagan, and G. Güzeldere (eds.), The nature of consciousness: philosophical debates. Cambridge MA: MIT Press, 1997. 
Meinong, A. (1904). On the theory of objects. In R. Chisholm (Ed.), Realism and the background of phenomenology. Glencoe: Free Press. 1960.

Merlan, P. (1945). Brentano and Freud. Journal of the History of Ideas, 6, 375-377.

Russell, B. (1905). Review of A. Meinong, Untersuchungen zur Gegenstandstheorie und Psychologie. Mind, 14, 530-538.

Sartre, J.-P. (1936). La Transcendance de l'ego. Paris: Vrin.

Sartre, J.-P. (1943). L'Etre et le néant. Paris: Gallimard.

Searle, J. R. (1990). Consciousness, explanatory inversion and cognitive science. The Behavioral and Brain Sciences, 13, 585-642.

Searle, J. R. (1992). The rediscovery of mind. Cambridge: MIT Press.

Siewert, C. P. (1998). The significance of consciousness. Princeton: Princeton UP.

Strawson, G. (1994). Mental reality. Cambridge: MIT Press.

Strawson, G. (2008). In his Real Materialism and Other Essays. Oxford: Oxford UP. Real Intentionality 3: Why Intentionality Entails Consciousness.

Twardowski, K. (1894). On the content and object of presentations. Trans. R. Grossmann. The Hague: Martinus Nijhoff, 1977.

von Ehrenfels, C. (1890). 'On Gestalt Qualities.' Trans. B. Smith. In B. Smith (ed.), Foundation of Gestalt Theory. Munich and Vienna: Philosophia, 1988.

von Ehrenfels, C. (1897/8). System der Verttheorie. Leipzig: Reisland. 